\title{
Proximate Composition and Heavy Metal Analysis of Three Aquatic Foods in Makoko River, Lagos, Nigeria
}

\author{
Isaac Opeyemi Ayanda $\mathbb{D}^{1},{ }^{1}$ Gabriel Adewumi Dedeke, ${ }^{2}$ Ukinebo Imuentiyan Ekhator, ${ }^{1}$ \\ and Mary Kufreabasi Etiebet ${ }^{1}$ \\ ${ }^{1}$ Department of Biological Sciences, Covenant University, Ota, Ogun State, Nigeria \\ ${ }^{2}$ Department of Pure and Applied Zoology, Federal University of Agriculture, Abeokuta, Ogun State, Nigeria
}

Correspondence should be addressed to Isaac Opeyemi Ayanda; opeyemi.ayanda@covenantuniversity.edu.ng

Received 22 January 2018; Revised 8 April 2018; Accepted 17 April 2018; Published 14 May 2018

Academic Editor: Elena González-Fandos

Copyright (C) 2018 Isaac Opeyemi Ayanda et al. This is an open access article distributed under the Creative Commons Attribution License, which permits unrestricted use, distribution, and reproduction in any medium, provided the original work is properly cited.

\begin{abstract}
Three aquatic products, tilapia fish, lobster and crab, were collected from the landing site of fishermen in Makoko, a fishing suburb in Lagos State, Nigeria. They were analyzed for their proximate composition, and concentration of heavy metals $(\mathrm{Cr}, \mathrm{Cd}$, and $\mathrm{Pb})$ was also measured in them. The nutrient values varied among the three organisms. The lobsters and crabs had higher protein values while tilapia was richer in lipid and moisture content. In most cases, these differences were not significant. The concentration of heavy metals also differed in the three organisms. All organisms had high concentrations of the three heavy metals analyzed. The heavy metal load as observed in this study is consistent with some previously reported values in literature. Plausible reasons for these differences were discussed in light of size, trophic level, choice of food of the organisms, and anthropogenic activities. It may be advisable that heavy metal concentrations are regularly monitored in edible aquatic food products so that human health is not at risk.
\end{abstract}

\section{Introduction}

Any life form in the sea is seen as food by man as seafood. This can range from fish, shellfish, shrimps, oysters, and so on. Seafood has primarily been a component of the diet of man in several countries and is a significant nutrient source, particularly of highly edible proteins [1]. They are also an outstanding source of vitamins, minerals, and omega-3 fatty acid, a daily nutrient requirement recommended by the American Heart Association. In addition to improving brain development, omega- 3 fatty acid has been shown to give protection against stroke and heart disease.

Fish is a typical example of seafood. It is a very vital source of animal protein from the tropical environment, and it is agreed to be a genuine source of important nutrients for maintaining a healthy body [2]. Compared to other sources of protein, fish are well known to be excellent sources of protein as they contain all the naturally occurring amino acids [3]. Tilapia is the common name for fish species in the family Cichlidae. One of the species in the Tilapia group is Oreochromis niloticus. It is a widely cultured species, occurring in the freshwater habitat. They are primarily vegetarian; their diet consists of readily abundant algae and plankton, thus contains low level of mercury [4]. O. niloticus is regarded as low in calories, saturated fat, potassium, carbohydrates and sodium, phosphorus, niacin, selenium, and vitamin B12, but a good protein source [5].

Crabs are an essential fishery product. Crabs are broadly dispersed in the tropical and calm areas of the world. Furthermore, they rank highly together with lobsters and shrimps for the fishery value they support and for their esteemed seafood delicacy [6]. Not only do crab species all over the world provide a direct food source, they are also used as fertilizers and as food additives [7]. Its taste makes it a delicacy everywhere it is found around the world. It contains minerals like calcium, copper, zinc, phosphorus, and iron in abundance with less amounts of chromium and selenium [8]. 
Lobsters are invertebrates that feed mainly on fish and mollusks, but also consume plant life especially algae. Lobsters are rich in copper, selenium, zinc, phosphorus, vitamin B12, magnesium, and vitamin E. They are highly prized, economically important seafood and can be profitable commodities in the waters they inhabit. Over the decades, lobsters have been widely fished throughout much of the West Africa [9]. A report suggests that individuals consuming shellfish like lobsters may reduce their risk of myocardial infarction by more than $50 \%$ [10].

The contributions of heavy metal, through effluents and runoff from agricultural lands, to environmental pollution cannot be overemphasized. Reduction in the quality of water and other edible aquatic life are just a few of the consequences of heavy metal discharge into the aquatic ecosystem. Furthermore, adverse biological effects in the form of an aquatic organism's survival, reproductive ability, metabolism, growth, and activity are other impacts of heavy metal pollution [11].

Due to the trophic level of fish in the aquatic food chain, accumulation of heavy metals from any of water, sediments or food becomes very easy $[12,13]$. All the valuable health benefits of fish may suddenly become detrimental if heavy metals store up in their bodies over a long time period [14]. This can be in the form of damage to the kidney, liver, cardiovascular diseases, and in extreme cases, even death $[15,16]$. Other aquatic products like shrimps, lobsters, and crabs are also considered to be major sources of heavy metals for the consumers [17]. They have been discovered to have a high sensitivity to metals and can accumulate high concentrations of metals from their environment [18]. These elements are eventually passed to higher levels of food chain and finally to human beings $[19,20]$.

There is a lot of research on heavy metal studies and proximate composition (moisture, ash, lipid, crude protein, and carbohydrate contents) of fish. However, there is a neglect of other edible aquatic products. The nutraceutical benefits of seafood have encouraged its continuous consumption. It may therefore be imperative to determine the concentrations of heavy metals in these seafoods as well as provide information on their nutritional composition in order to help make informed decision when aquatic products are to be consumed.

\section{Materials and Methods}

The study area, Makoko, with coordinates $6^{\circ} 29^{\prime} 44^{\prime \prime} \mathrm{N}, 3^{\circ}$ $23^{\prime} 39^{\prime \prime} \mathrm{E}$ is shown in Figure 1 below. It is situated in Makoko, one of three small communities on the coast of Lagos mainland, Lagos State, Nigeria. It is entirely a fishing community. The water in this community is an overflow from the open sea, with a tendency to become brackish especially during peak periods of the rain. Hence, the catches from this water body cut across both salt and fresh water. It has a sandy bottom, but it is murky water due to serious anthropogenic activities that is ongoing in the area. Industrial activities around the coastlines also abound.

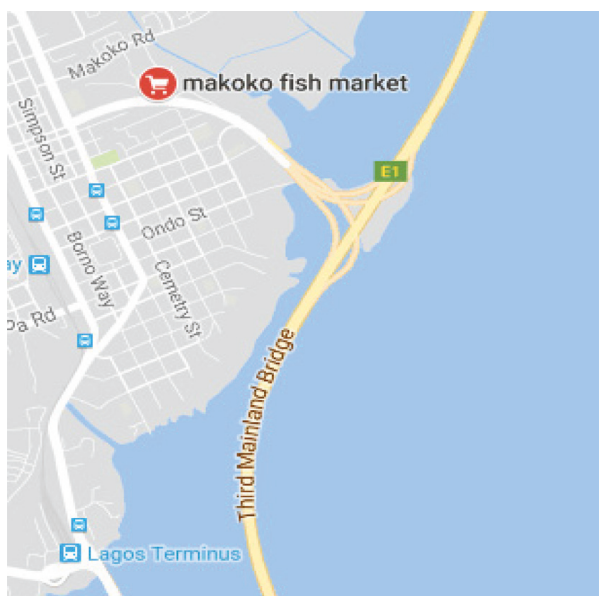

FIGURE 1: Makoko river map showing site of sampling (Makoko fish market).

2.1. Sample Collection. The aquatic products, tilapia fish, lobsters, and crabs were bought directly from fishermen at their landing site around the Makoko market, Lagos State, Nigeria. 20 samples each of the fish, crab, and lobsters were used for this experiment. The samples were taken in ice cold box to the laboratory where they were weighed, measured, and kept at $-20^{\circ} \mathrm{C}$ until analysis. All samples of fish, lobsters, and crabs were washed thoroughly, and the fillets were taken for determination of the proximate composition.

\subsection{Proximate Analysis}

2.2.1. Moisture Content. The amount of moisture in the organisms was determined according to AOAC [21]. Samples were dried in an air oven at $101^{\circ} \mathrm{C}$ for about 10 hours until constant weights were obtained, cooled in a desiccator, and reweighed. Moisture content was taken to be the differential between fresh and dry weights.

2.2.2. Ash Content. Dried samples obtained in the process of moisture content determination were heated in a muffle furnace at $550^{\circ} \mathrm{C}$ for several hours. The percentage of ash was calculated by subtracting the weight of ash from the initial weight.

2.2.3. Crude Protein Content and Carbohydrate. Crude protein was analyzed by the Kjeldahl method [21]. The samples went through the three essential steps of digestion, distillation, and titration using a conversion factor of 6.25 to convert total nitrogen to crude protein. The percentage of protein in the samples was calculated thereafter. Subtracting the sum of fat content, protein content, ash content, and moisture from 100 gave the total carbohydrate content [22].

2.2.4. Fat Content. Crude fat was determined by weighing $5 \mathrm{~g}$ of each sample wrapped in a filter paper in a Soxhlet apparatus using petroleum ether. This was done each for 
TABLE 1: Information on the diet of the three seafoods.

\begin{tabular}{|c|c|c|c|c|c|}
\hline Common name & Scientific name & $n$ & Av. eweight & Av. length & Food choice \\
\hline Tilapia & Oreochromis niloticus & 20 & $979 \pm 126.34$ & $32 \pm 1.1$ & $\begin{array}{c}\text { Plant tissue, phytoplankton, small fish, detritus, small } \\
\text { aquatic organisms }\end{array}$ \\
\hline Lobster & & 20 & & & Phytoplankton, small fish, 1 \\
\hline Crab & Sudanonautes africanus & 20 & $80 \pm 8.66$ & $13 \pm 1.58$ & Algae, insects, detritus, plants, sand grains \\
\hline
\end{tabular}

4 hours. The extracted materials left after the solvent had evaporated were weighed, and the fat content was calculated.

2.3. Heavy Metal Analysis. Frozen samples of each of the aquatic product were thawed. The fishes were dissected, and their muscles and livers were removed using dissecting equipment and separately analyzed. Body parts of both the crabs and lobsters were also taken for this analysis. $1 \mathrm{~g}$ of oven-dried samples was made into fine powder for digestion. The samples were digested with concentrated nitric and hydrochloric acid in the ratio $3: 1$, and the mixture was placed on a water bath until the colour changes. The resulting solution was cooled, filtered into a $100 \mathrm{ml}$ standard flask and made to mark with distilled water [23]. The heavy metals (chromium, cadmium, and lead) were determined using flame furnace atomic absorption spectrophotometry (S Series Thermo Electron USA). Each sample set has its own blank, while correction/adjustment was made through reference to the blank. In the course of the experiment, glassware were washed with acid and distilled water twice. All reagents were of analytical grade. Certified reference material was checked to ensure of the analytical procedure.

2.4. Statistical Analysis. The heavy metal values were means of three measurements. The proximate values for the three aquatic products were means for ten organisms. One-way ANOVA was used to determine significant differences in levels of heavy metals among fish (liver and muscle), lobsters, and crabs. Duncan test was used for mean comparison.

\section{Results}

The average weights and lengths of the three aquatic organisms used for this study are represented in Table 1. The table also compares the diets of the organisms. The tilapia fish is the biggest in size among the three aquatic organisms as can be seen from the table. This probably is because there is a maximum limit to which the other two organisms can grow. The crabs are next in size, and the lobsters are of the smallest size. There is a similarity in the food items consumed by the three aquatic organisms. Plant material (phytoplankton, algae) cuts across their foods. It can also be said that the organisms use varieties of aquatic life as food; hence, they are flexible in their choice of food.

The percentage mean proximate composition of the three aquatic organisms is presented in Table 2. Crude protein is highest in crab, closely followed by lobster, and least in the tilapia fish. These difference in these values are however not statistically significant. Ash content is also highest in crab though it is followed by tilapia and lobster has
TABLE 2: The percentage mean proximate composition of the three seafoods.

\begin{tabular}{lccc}
\hline Parameters (\%) & Tilapia fish & Lobster & Crab \\
\hline Crude protein & $23.75^{\mathrm{a}}$ & $24.10^{\mathrm{a}}$ & $26.87^{\mathrm{a}}$ \\
Ash & $2.43^{\mathrm{a}}$ & $2.28^{\mathrm{a}}$ & $2.48^{\mathrm{a}}$ \\
Moisture & $72.22^{\mathrm{a}}$ & $71.63^{\mathrm{a}}$ & $70.60^{\mathrm{a}}$ \\
Fat & $1.42^{\mathrm{a}}$ & $1.03^{\mathrm{b}}$ & $0.54^{\mathrm{c}}$ \\
Carbohydrate & $0.24^{\mathrm{a}}$ & $0.13^{\mathrm{b}}$ & $0.22^{\mathrm{a}}$ \\
\hline
\end{tabular}

Values with the same superscript, within the same row, shows no significant difference while those with different superscript within the same row shows significant difference.

TABLE 3: Mean $( \pm S D)$ concentration of heavy metals $(\mathrm{mg} / \mathrm{kg})$ in the different seafoods.

\begin{tabular}{lcccc}
\hline Heavy metal & Fish muscle & Fish liver & Lobster & Crab \\
\hline Chromium & $4 \pm 2.0^{\mathrm{a}}$ & $1 \pm 0.00^{\mathrm{b}}$ & $4 \pm 1.00^{\mathrm{a}}$ & $5 \pm 1.00^{\mathrm{a}}$ \\
Cadmium & $2 \pm 1.9^{\mathrm{a}}$ & $1 \pm 0.00^{\mathrm{a}}$ & $21 \pm 1.00^{\mathrm{b}}$ & $3 \pm 2.00^{\mathrm{a}}$ \\
Lead & $29 \pm 2.1^{\mathrm{a}}$ & $31 \pm 1.1^{\mathrm{a}}$ & $23 \pm 1.3^{\mathrm{a}}$ & $28 \pm 1.4^{\mathrm{a}}$ \\
\hline
\end{tabular}

Values with the same superscript, within the same row, shows no significant difference while those with different superscript within the same row shows significant difference.

the least Ash content. Statistically, these values also do not reveal any significant difference between them. Moisture and content, as expected, form the bulk of the proximate values in the body of the organisms. It is highest in tilapia fish, followed by lobster, and lowest in the crab. Furthermore, these values are not statistically different. The proximate values for the fat content are similar to what is observed in moisture content in following the order of being highest in tilapia $>$ lobster $>$ crab. However, the values in the three organisms are significant. The carbohydrate values are highest in the fish, closely followed by the crab though they are not significant. Carbohydrate is significantly lower in the lobster than the two other organisms.

The mean concentrations of heavy metals in the three aquatic organisms are presented in Table 3 . The heavy metals were analyzed for in both fish muscle and liver. Chromium was highest in crab and then in fish muscle and lobster. It is significantly lowest in the liver of fish. Cadmium is highest in lobster and significantly so in comparison with values in the other two aquatic organisms. This is followed by crab, fish muscle, and fish liver. The values of lead in all four samples analyzed are not significantly different from one another. It is highest in fish (liver > muscle), then crab, and lowest in lobster.

\section{Discussion}

The three aquatic species are good protein sources. Protein has been reported to be the most vital biomolecule in 
crustaceans, from eggs to adulthood, and is conspicuously dominant in young phases [24]. Crab had the highest protein value $(26.87 \%)$ of the three animals. This finding is not too different from that of Fagbuaro et al. [25] who reported protein values between $19 \%$ and $22 \%$ in Sudanonautes africanus. However, the protein value of fish reported here (23.75\%) was comparably lower than what was reported by Fawole et al. [26] who reported about $38.40 \%$ in O. niloticus. As opined by them, these differences may be attributed to absorption capability and conversion potentials of essential nutrients from their diets. Furthermore, in this case, it may be as a result of differences in the aquatic environment from where the fishes were sampled. Comparing human consumption preference in the three organisms, fish, which had the lowest protein value, is the most preferred. The reasons for this may not be far-fetched. First is that fish is more readily available than the two other organisms. In addition to this is the fact that it is very tasty for the majority of its consumers who may be unwilling to trade this for other tastes. Secondly, the aesthetic value of fish is higher than the other two, and unfortunately, some persons do not even regard either the lobsters or crabs as sources of meat. Lastly, the size of the fish is also a factor. As can be seen in Table 1, fish is bigger than the other two animals. This will mean that a single fish will feed the same number of persons as about four or five crabs and lobsters will do if they are to be considered as alternatives to fish, with the possibility that it may even cost more. However, as can be seen from this study, it may be important to educate persons to put the sentimental attachments stated above aside when it comes to the choice of food (specifically protein) from the aquatic environment, and begin to look at other aquatic foods. This is because other than the fact that the lobsters and crabs have more protein than fish, their carapace is also a very rich constituent of calcium. Calcium is one of the major mineral elements that must be ensured is not in short supply in the body. Its primary function in the mineralization of bone cannot be overemphasized. Added to this is its function as a cofactor in enzymatic processes and its participation in the structure of the DNA self-repair system [27].

Moisture content of a given sample is the measure of its water content. The results in Table 1 showed variation in the values of moisture content obtained with tilapia fish having the highest moisture content $(72.22 \%)$, followed by lobster $(71.63 \%)$ then crab $(70.60 \%)$. The skin of fish is soft compared to the thick carapace of lobsters and crabs. This allows for easy permeability of water through skinwater interface, as such can easily acquire more water into its body. High moisture content is good for organisms as it will allow enzymatic reactions go on smoothly. However, high moisture content can also be disadvantageous by making the fish susceptible to spoilage by microbes, increasing oxidative degradation of polyunsaturated fatty acids and ultimately decrease the quality of fish thereby reducing its preservation time [28].

Ash measures the mineral content in an organism. It is the inorganic remnant of burnt organic matter. The results in Table 1 showed ash content in the three organisms in the order crab $>$ fish $>$ lobster. The differences in the concentration of minerals may be influenced by different factors including seasonal changes, age, sex, size, and sexual maturity, food source, and availability in the respective habitat of organisms and other factors such as water chemistry, salinity, temperature, and contaminants [29, 30].

Lipids are an alternative energy source in times of fasting and starvation. As can be seen in Table 1, tilapia had the highest fat content (1.42\%) and crab had the least $(0.54 \%)$. The fat content was significantly higher in fish. Fats are important in the structural and biological functioning of the cells. In crustaceans, not only do lipids function as the main organic reserve and source of metabolic energy but are also indispensable in maintaining cellular integrity. Generally, lipids act as major food reserve together with protein and may fluctuate periodically due to environmental variable like temperature [24]. The differences in proximate composition could be due to structural makeup of their bodies. The skin of animals in comparison to carapace is a rich area of fat. The three species can be ideal diet foods.

The mean heavy metal loads in the bodies of the three organisms are presented in Table 3 . The mean concentration of chromium in tilapia fish, liver of tilapia fish, lobster, and crab were $4 \pm 3.0,1 \pm 0.00,4 \pm 1.00$ and $5 \pm 1.00 \mathrm{mg} / \mathrm{kg}$, respectively. The mean concentration of heavy metal in crab was the highest compared to that in tilapia fish, liver of tilapia fish, and lobster. Chromium has been implicated in increasing the risk of lung cancer when it aquatic organisms which harbors it are consumed [31]. It has been reported that accumulation of heavy metals in a tissue is primarily a reflection of water concentrations of metals and exposure time [32]. These reported values are probably a reflection of the level of chromium present in the water body. Naturally, chromium gets into water bodies through leaching from topsoil and rocks especially during rock weathering. There are no rocks in the areas of this water body, and so chromium may not have got access to water through this means. Anthropogenic activities like electroplating, leather tanning, and textile production are the other means by which this heavy metal may escape into the aquatic environment [33]. There are probably pockets of these activities around the water body but obviously they are not introducing chromium into the water body in scary amounts. The highest mean concentration of chromium $(5 \pm 1.00 \mathrm{mg} / \mathrm{kg})$ found in crab is relatively high; however, there is no significant difference in this value and the values in fish muscle and lobsters. A plausible reason for this might be that crabs also eat a lot of aquatic insects (Table 1). Aquatic insects have been reported to be very good indicators of heavy metal pollution; they accumulate it in relation to water concentration levels [34]. This is because chromium is a trace element that plays a very crucial role in the metabolism of glucose [35]. Deficiency of chromium may lead to slow down development and can also disrupt metabolism of protein, lipid, and glucose [36].

The mean concentration of cadmium in the tissue of the three species and liver of tilapia fish is presented in Table 3. The mean concentration of cadmium in tilapia fish, liver of tilapia fish, lobster, and crab were $2 \pm 1.9,1 \pm 0.00,21 \pm 1.00$, and $3 \pm$ $2.00 \mathrm{mg} / \mathrm{kg}$, respectively. Cadmium levels are very high in all 
cases. This may imply serious health risks for its consumers. Cadmium is considered a very toxic heavy metal. There are two reasons why cadmium toxicity is a major ecological concern: its ability to accumulate very quickly and its slow process of depuration [37]. It can induce pathological changes, ranging from necrosis in the pancrease, engorgement of blood vessels, and vacuolar degeneration of hepatocytes [38]. The significantly higher values in lobster as compared to fish may be due to size, in terms of length and weight. According to Velusamy et al. [39], the size of marine organisms play an important role in accumulation of metals. Nussey et al. [40] and Widianarko et al. [41] both reported decreasing values of heavy metal load with increasing length of animals. This difference can also further be explained in terms of feeding behavior and habitat. Tilapia is a primarily herbivorous fish, depending mainly on food of plant origin as can be seen in Table 1, which means that they occupy a lower trophic level. Lobsters, on the other hand, are omnivorous, additionally utilizing food of animal origin making them diverse in their food choice. This diversity will lead to higher biomagnification [42].

Table 3 shows the mean concentrations of lead in the tissue of the three species and the liver of tilapia fish. The mean concentration of lead in tilapia fish, liver of tilapia fish, lobster, and crab were $29 \pm 2.1,31 \pm 1.1,23 \pm 1.3$, and $28 \pm$ $1.4 \mathrm{mg} / \mathrm{kg}$, respectively. The lead concentration is very high. Anake et al. [43] had also reported high levels of lead from different water sources. These findings might indicate the high presence of lead distributed all through this water body. A lot of anthropogenic activities like exhaust from automobiles, agricultural runoff, and fish antifouling paints would have cumulatively introduced lead the water where it is readily available for uptake by aquatic organisms [44]. Furthermore, the liver of fish might have tendencies to accumulate high levels of heavy metals. This may be due to the detoxification role of the liver. Benson et al. [45] also reported high mercury levels in fish liver. This is very threatening to the health of man considering the effects of lead toxicity. Brain damage, paralysis, anaemia, and gastrointestinal symptoms are a few of the symptoms of lead toxicity in humans.

In conclusion, the three seafoods have shown to be good sources of nutrients which are essential for the maintenance of a healthy body. While the lobsters and crabs are particularly rich in protein, the fish is rich in lipid content. Unfortunately, despite the richness in protein of lobster and crab, they also harbor high heavy metal concentrations. However, these high levels are obviously a function of the pollution status of the particular water body as this heavy metal levels is high in all organisms sampled. Other natural water bodies, with no or very low heavy metal pollution, and where these aquatic organisms live should be considered as good sources of aquatic food. The high levels of heavy metals pollution reported here calls for concern. It will be important that regulatory agencies monitor anthropogenic activities around the water body in order to avoid crisis to human health in the near future.

\section{Data Availability}

All data from the study are as presented in this article.

\section{Conflicts of Interest}

The authors declare no conflicts of interest.

\section{Funding}

Research was funded by the authors.

\section{References}

[1] T. A. Faber, D. C. Hernot, C. M. Parsons et al., "Protein digestibility evaluations of meat and fish substrates using laboratory, avian, and ideal cannulated dog assays," Journal of Animal Science, vol. 88, no. 4, pp. 1421-1432, 2010.

[2] A. E. Andrew, Fish-Processing Technology, University of Ilorin Press Nigeria, Ilorin, Nigeria, 2001.

[3] N. Louka, F. Juhel, and K. Allaf, "Quality studies on various types of partially dried vegetables texturized by controlled sudden decompression: general patterns for the variation of the expansion ratio," Journal of Food Engineering, vol. 65, no. 2, pp. 245-253, 2004.

[4] J. K. McCrary, M. Castro, and K. R. McKaye, "Mercury in fish from two Nicaraguan lakes: a recommendation for increased monitoring of fish for international commerce," Environmental Pollution, vol. 141, no. 3, pp. 513-518, 2006.

[5] E. Trewavas, Tilapiine Fishes of the Genera Sarotherodon, Oreochromis and Danakilia, British Museum (Natural History), London, UK, 1983.

[6] A. M. Savad and P. R. Rahavan, "Mud crab-culture and fattening techniques, status and prospects," Seafood Export Journal, vol. 32, pp. 25-29, 2001.

[7] P. Gülle, Determination of some biological properties of Potamon (Potamon) Potamios (Olivier, 1804) living at lake Egirdir, Master thesis, p. 45, Institute of Science Turkey, Univ Süleyman Demirel, Isparta, Turkey, 2005.

[8] E. I. Adeyeye, "Determination of the chemical composition of the nutritionally valuable parts of male and female common West African fresh water crab Sudananautes africanus africanus," International Journal of Food Science and Nutrition, vol. 53, no. 3, pp. 189-196, 2014.

[9] R. Freitas, A. Medina, and M. Castro, "Reproductive biology of spiny lobster Panulirus regius from the north-western Cape Verde Islands," African Journal of Marine Science, vol. 29, no. 2, pp. 201-208, 2007.

[10] J. M. Yuan, R. K. Ross, Y. T. Gao, and M. C. Yu, "Fish and shellfish consumption in relation to death from myocardial infarction among men in Shanghai, China," American Journal of Epidemiology, vol. 154, no. 9, pp. 809-816, 2001.

[11] D. A. Wright and W. Pamela, Environmental Toxicology, Cambridge University Press, Cambridge, UK, 2002.

[12] F. Yilmaz, N. Ozdemir, A. Demirak, and A. L. Tuna, "Heavy metal levels in two fish species Leuciscus cephalus and Lepomis gibbosus," Food Chemistry, vol. 100, no. 2, pp. 830-835, 2007.

[13] S. Zhao, C. Feng, W. Quan, X. Chen, J. Niu, and Z. Shen, "Role of living environments in the accumulation characteristics of heavy metals in fishes and crabs in the Yangtze River Estuary, China," Marine Pollution Bulletin, vol. 64, no. 6, pp. 11631171, 2012.

[14] M. I. Castro-González and M. Méndez-Armenta, "Heavy metals: Implications associated to fish consumption," Environmental Toxicology and Pharmacology, vol. 26, no. 3, pp. 263-271, 2008.

[15] M. Al-Busaidi, P. Yesudhason, S. Al-Mughairi, W. A. K. AlRahbi, K. S. Al-harthy, and Al-Mazrooei, "Toxic metals in 
commercial marine fish in Oman with reference to national and international standards," Chemosphere, vol. 85, no. 1 , pp. 67-73, 2011.

[16] M. S. Rahman, A. H. Molla, N. Saha, and A. Rahman, "Study on heavy metals and its risk assessment in some edible fishes from Bangshi river, Savar, Dhaka, Bangladesh," Food Chemistry, vol. 134, no. 4, pp. 1847-1854, 2012.

[17] M. Dural, L. Z. Goksu, A. A. Ozak, and B. Derici, "Bioaccumulation of some heavy metals in different tissues of Dicentrachus labax from the Camlik Lagoon of the eastern cost of Mediterranean," Environmental Monitoring and Assessment, vol. 118, no. 1-3, pp. 65-74, 2006.

[18] Y. Bambang, P. Thuet, M. Charmantier-Daures, J. P. Trilles, and G. Charmantier, "Effect of copper on survival and osmoregulation of various developmental stages of the shrimp Penaeus japonicus Bate (Crustacea, Decapoda)," Aquatic Toxicology, vol. 33, no. 2, pp. 125-139, 1995.

[19] M. H. Al-Yousuf, M. S. EL-Shahawi, and S. M. Al- Ghais, "Trace metals in liver, skin and muscle of Lethrinus lentjan fish species in relation to body length and sex," Science of the Total Environment, vol. 256, no. 2-3, pp. 87-94, 2000.

[20] P. L. Palaniappan and S. Karthikeyan, "Bioaccumulation and depuration of chromium in the selected organs and whole body tissues of freshwater fish Cirrhinus mrigala individually and in binary solutions with nickel," Journal of Environmental Science, vol. 21, no. 2, pp. 229-236, 2009.

[21] AOAC, Official Methods of Analysis of the Association of the Official Analytical Chemists, 17th edition, AOAC International, Washington, DC, USA, 2000.

[22] E. N. Onyeike, E. O. Ayoologu, and C. O. Ibegbulam, "Evaluation of the nutritional value of some crude oil in polluted freshwater fishes," Global Journal of Pure and Applied Sciences, vol. 6, no. 2, pp. 227-233, 2000.

[23] P. O. Gagophien and J. E. Nwajei, "Distribution of heavy metals in the sediment of Lagos Lagoon," Pakistan Journal of Scientific and Industrial Research, vol. 43, no. 6, pp. 338-340, 2000.

[24] D. Varadharajan and P. Soundarapandian, "Proximate composition and mineral contents of freshwater crab Spiralothelphusa hydrodroma (Herbst, 1794) from Parangipettai, South East Coast of India," Journal of Aquatic Research Development, vol. 5, no. 2, p. 217, 2014.

[25] O. Fagbuaro, F. A. Majolagbe, and J. A. Oso, "Proximate composition and mineral content of the land crab Sudanonautes africanus," Journal of Scientific Research and Reports, vol. 3, no. 2, pp. 349-355, 2014.

[26] O. O. Fawole, M. A. Ogundiran, T. A. Ayandiran, and O. F. Olagunju, "Proximate and mineral composition in some selected fresh water fishes in Nigeria," Internet Journal of Food Safety, vol. 9, pp. 52-55, 2007.

[27] M. Fenech, "The genome health clinic and genome health nutrigenomics concepts: diagnosis and nutritional treatment of genome and epigenome damage on an individual basis," Mutagenesis, vol. 20, no. 4, pp. 255-269, 2005.

[28] O. Omolara and O. Omotayo, "Preliminary Studies on the effect of processing methods on the quality of three commonly consumed marine fishes in Nigeria," Biokemistri, vol. 21, no. 1, pp. 1-7, 2009.

[29] M. Hassan, Influence of pond fertilization with broiler dropping on the growth performance and meat quality of major carps, Ph.D. thesis, University of Agriculture, Faisalabad, Pakistan, 1996.

[30] A. Kucukgulmez, M. Celik, Y. Yanar, B. Ersoy, and M. Cikrikci, "Proximate composition and mineral contents of the blue crab
(Callinectes sapidus) breast meat, claw meat and hepatopancrease," International Journal of Food Science and Technology, vol. 41, no. 9, pp. 1023-1026, 2006.

[31] Y. Ishikawa, K. Nagakawa, Y. Satoh et al., "Characteristics of chromate workers cancers, chromium lung deposition and precancerous bronchial lesions: an autopsy study," British Journal of Cancer, vol. 70, no. 1, pp. 160-170, 1994.

[32] M. Canli and G. Atli, "The relationship between heavy metal $(\mathrm{Cd}, \mathrm{Cr}, \mathrm{Cu}, \mathrm{Fe}, \mathrm{Pb}, \mathrm{Zn})$ levels and the size of six Mediterranean fish species," Environmental Pollution, vol. 121, no. 1, pp. 129-136, 2003.

[33] F. Zhou, H. Guo, and Z. Hao, "Spatial distribution of heavy metals in Hong Kong's marine sediments and their human impacts: a GIS-based chemometric approach," Marine Pollution Bulletin, vol. 54, no. 9, pp. 1372-1384, 2007.

[34] R. B. Nehring, "Aquatic insects as biological monitors of heavy metal pollution," Bulletin of Environmental Contamination and Toxicology, vol. 15, no. 2, pp. 147-154, 1976.

[35] W. Mertz, "Chromium occurrence and function in biological system," Physiological Reviews, vol. 49, pp. 163-239, 1969.

[36] E. J. Calabrese, A. T. Canada, and C. Sacco, "Trace elements and public health," Annual Reviews of Public Health, vol. 6, no. 1, pp. 131-146, 1985.

[37] R. C. Okocha and O. B. Adedeji, "Overview of cadmium toxicity in fish," Journal of Applied Sciences Research, vol. 7, no. 7, pp. 1195-1207, 2005.

[38] A. J. Dangre, S. Manning, and M. Brouwer, "Effects of cadmium on hypoxia-induced expression of hemoglobin and erythropoietin in larval sheep is head minnow, Cyprinodon variegates," Aquatic Toxicology, vol. 99, no. 2, pp. 168-175, 2010.

[39] A. Velusamy, P. SatheeshKumar, A. Ram, and S. Chinnadurai, "Bioaccumulation of heavy metals in commercially important marine fishes from Mumbai Harbor, India," Marine Pollution Bulletin, vol. 81, no. 1, pp. 218-224, 2014.

[40] G. Nussey, J. H. J. Van Vuren, and H. H. du Preez, "Bioaccumulation of chromium, manganese, nickel and lead in the tissues of the moggel, Labeo umbratus (Cyprinidae), from Witbank dam, Mpumalanga," Water SA, vol. 26, pp. 269-284, 2000.

[41] B. Widianarko, C. A. M. Van Gestel, R. A. Verweij, and N. M. Van Straalen, "Associations between trace metals in sediment, water, and guppy, Poecilia reticulata (Peters), from urban streams of Semarang, Indonesia," Ecotoxicology and Environmental Safety, vol. 46, no. 1, pp. 101-107, 2000.

[42] H. Rohasliney, H. S. Tan, M. Noor Zuhartini, and P. Y. Tan, "Determination of heavy metal fishes from the lower reach of Kelantan river, Kelantan, Malaysia," Tropical Life Science Research, vol. 25, no. 2, pp. 21-39, 2014.

[43] W. U. Anake, N. U. Benson, A. A. Akinsiku, C. O. Ehi-Eromosele, and I. O. Adeniyi, "Assessment of trace metals in drinking water and groundwater sources in Ota, Nigeria," International Journal of Scientific Research and Publications, vol. 4, no. 5, pp. 1-4, 2014.

[44] H. M. Leung, A. O. W. Leung, H. S. Wang et al., "Assessment of heavy metals/metalloid (As, $\mathrm{Pb}, \mathrm{Cd}, \mathrm{Ni}, \mathrm{Zn}, \mathrm{Cr}, \mathrm{Cu}, \mathrm{Mn}$ ) concentrations in edible fish species tissue in the Pearl river delta (PRD), China," Marine Pollution Bulletin, vol. 78, no. 12, pp. 235-245, 2014.

[45] N. U. Benson, J. P. Essien, A. B. Williams, and D. E. Bassey, "Mercury accumulation in fishes from tropical aquatic ecosystems in the Niger Delta, Nigeria," Current Science, vol. 92, no. 6, pp. 781-785, 2007. 


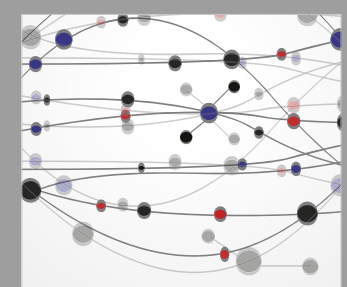

The Scientific World Journal
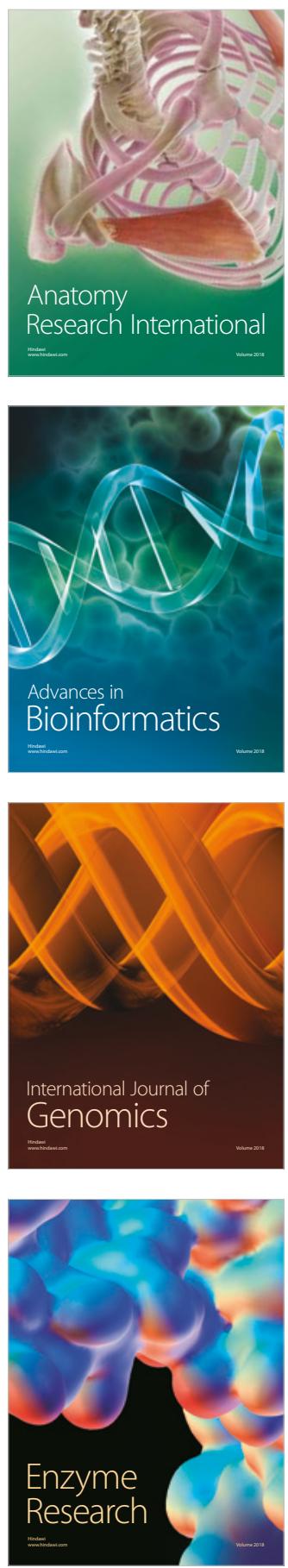
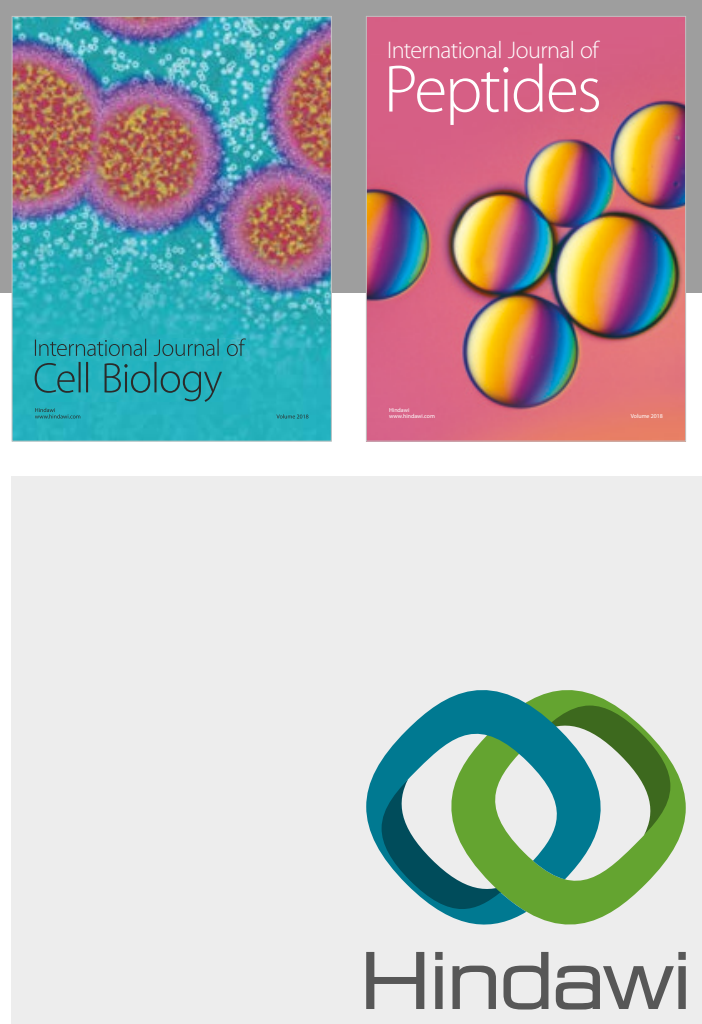

Submit your manuscripts at

www.hindawi.com
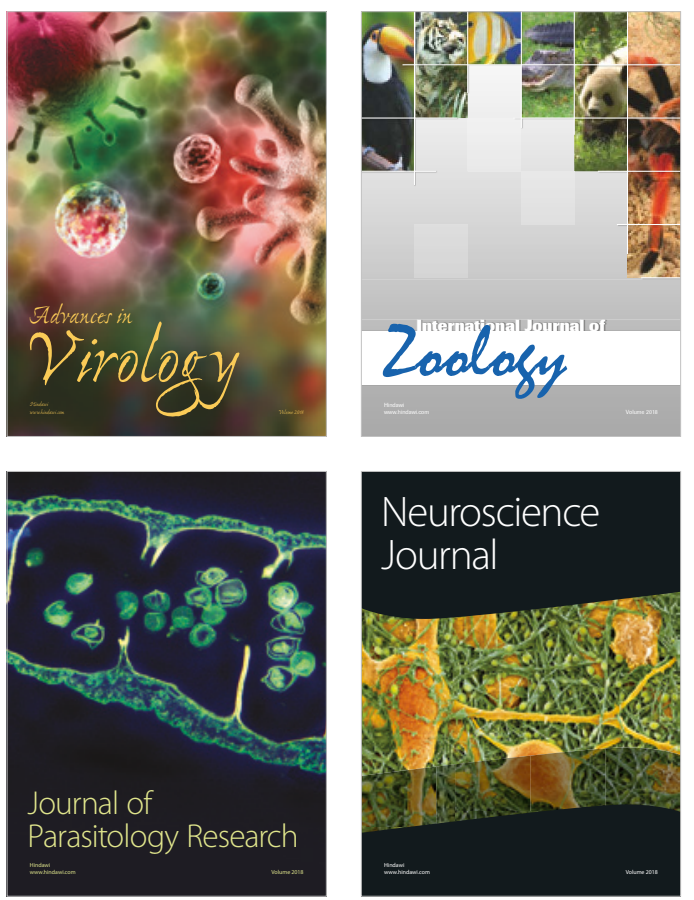
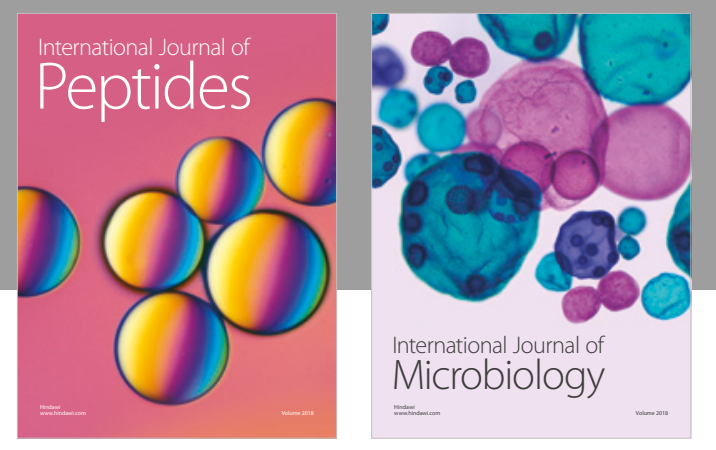

nternational Journal of Microbiology
Journal of
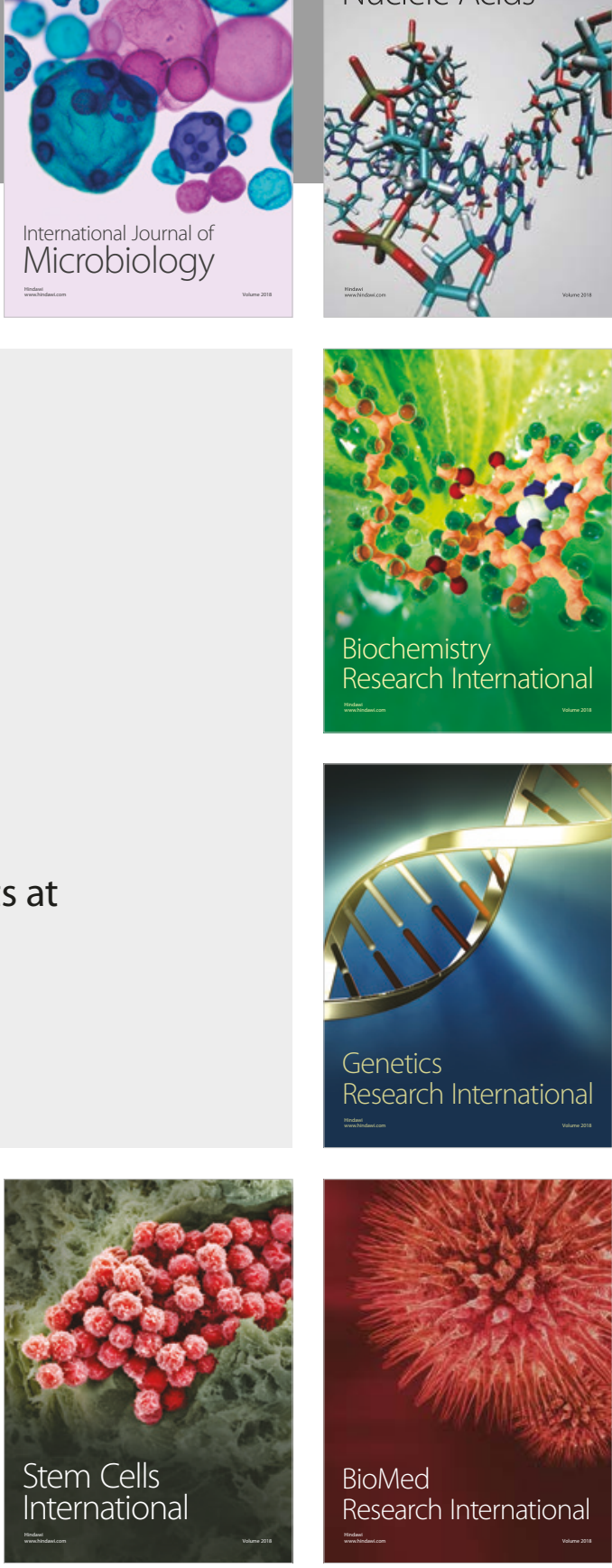
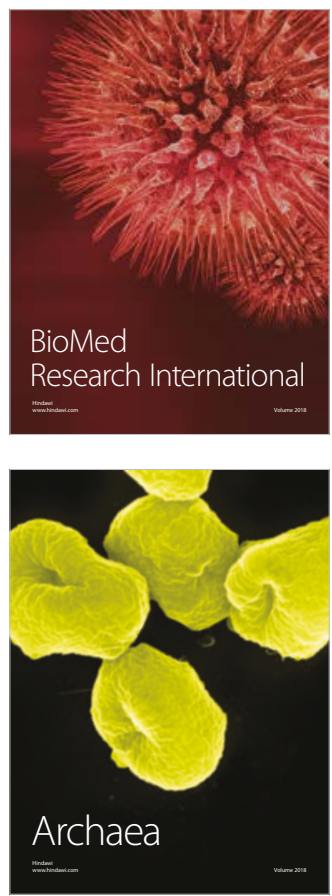